\title{
An Analysis of the Freshmen Alcohol Abuse Program
}

\author{
J. Joshua Brown \\ California State University, Chico
}

\begin{abstract}
The aim of this study is to assess outcomes of the Freshmen Alcohol Abuse Program in reducing BAC levels among freshmen students and to describe and learn about the patterns of drinking behaviors. This program is a combination of the "Wanna Know" and "Did You Know" campaigns. The Wanna Know campaign consisted of a blood alcohol concentration (BAC) test with a Breathalyzer ${ }^{\circledR}$ device and an interview with freshmen students on unannounced weekend "partying nights" on a northern California university campus. The interviews and breath tests totaled 1,314 in year one and 1,215 in year two. The Did You Know campaign was the component that focused on distributing social norming messages. Social norming messages were delivered through posters on campus, screensavers in student computing labs, mouse pads, brochures, table tent cards, and t-shirts. These messages were designed to curb drinking by making students aware of the actual drinking norms rather than the students' perceived norms with the intent that students would adjust to the actual norm, resulting in a reduction in drinking. Results indicated mean BAC levels of .068 in year one and .056 in year two. This represents a drop of .012 BAC, or a 21.4 percent decline from year one to year two.
\end{abstract}

(c) 2004 Californian Journal of Health Promotion. All rights reserved.

Keywords: alcohol abuse, social norms theory, Breathalyzer ${ }^{\circledR}$, freshmen college students, college health

\section{Introduction}

\section{Background}

In a 1989 survey, 67 percent of college and university presidents rated alcohol misuse to be "moderate" or a "major" problem on their campus (Carnegie Foundation for the Advancement of Teaching, 1990). Alcohol abuse by college students became even more of a national issue when students from Louisiana State University and the Massachusetts Institute of Technology died from alcohol poisoning in 1997. In response to these deaths, organizations such as Mothers Against Drunk Driving (MADD) and College Parents of America urged the nation to develop methods of preventing further deaths (DeJong \& Langford, 2002).

California State University, Chico (CSU, Chico) has had its share of alcohol problems. From 1996 to 2001 CSU, Chico lost five students from alcohol-related deaths. This includes freshman student Adrian Heideman, whose death in the fall of 2000 was the impetus for the Freshmen
Alcohol Abuse Program at CSU, Chico. Heideman had been a student for only a few weeks at CSU, Chico before the Pi Kappa Phi fraternity pledge passed out in the fraternity's basement and choked to death on his own vomit from drinking a bottle of blackberry brandy (Vau Dell, 2002).

Three Pi Kappa Phi fraternity members served jail sentences after pleading guilty to a misdemeanor for having contributed to the binge-drinking death. In addition, Adrian's mother, Edith Heideman, sued the fraternity for the wrongful death of her son (Vau Dell, 2001, 2002).

CSU, Chico has a reputation for being a "party school," which is partly due to the week-long celebration called Pioneer Days which had its origins in the early 20th century. In 1987, this celebration erupted in rioting, which led the existing CSU, Chico president, Robin Wilson, to cancel it (Flinn, 1989). To make matters worse, 
in January of that same year Playboy magazine ranked CSU, Chico the number one party school in the nation (Duvall, 1987). Because of CSU, Chico's party school reputation, some have argued that students may be attracted to the campus for the wrong reasons, while other academically and socially responsible students may be deterred from applying (Choat, 2002).

In 1988, Rancho Chico Days emerged as a spring celebration. It lasted for a couple of years before it too was canceled (Bizjak, 1990). Halloween, St. Patrick's Day, and the annual Sacramento River Float emerged as events that had to be regulated due to students' and out-oftowners' rowdy behavior. These events, often associated with alcohol consumption, have come under intense scrutiny by campus administrators, local law enforcement, and community leaders. Unfortunately, Playboy magazine ran their "party school" rankings once again in their November 2002 issue, and decided to place CSU, Chico in second place (Prato, 2002). According to former CSU, Chico President Manuel Esteban concerning the 2002 rankings, "in one easy stroke it undoes a lot of the effort that a lot of people have made in the last 15 years to get rid of the image" (Choat, 2002, p. 1). In addition, it should be noted that the magazine's methods of gathering the data were biased (self-selection bias). However, the ranking still may have damaged CSU, Chico's already-tarnished reputation (Choat, 2002).

Despite the bad publicity of the long-standing party school image, CSU, Chico is academically reputable. Take for example, the U.S. News and World Report rankings. As of 2004 CSU, Chico is ranked third in the top public Western universities for the master's program (nondoctorate) behind only Cal Poly-San Luis Obispo and Western Washington University, which ranked first and second, respectively (“America's Top Publics,” 2004). Currently CSU, Chico, is also ranked 29th among public and private schools in the West according to the U.S. News and World Report ("America's Top Schools,” 2004). In addition, the average grade point average (GPA) and scholastic aptitude test (SAT) scores of incoming freshmen is currently 3.3 and 1035, respectively, according to John
Swiney, admissions director at CSU, Chico (Gimblin, 2004). Certainly, a paradigm shift has occurred on this campus pointing toward a better future.

\section{Purpose of the Study}

The purpose of this study was to assess outcomes of the Freshmen Alcohol Abuse Program in reducing BAC levels among freshmen students between the academic years 2001-2002 to 2002-2003 and to describe and learn about the patterns of freshmen drinking behaviors. Freshmen students were targeted since alcohol abuse is widespread in first-year students. The Freshmen Alcohol Abuse Program was intended to decrease alcohol use in freshmen students in order to maintain improved social norms and alcohol-related values throughout the rest of their academic career (Schafer, 2001).

\section{Statement of the Problem}

Given the alcohol deaths at California State University, Chico and the programs associated with reducing problem drinking on the campus, the question arises: Did the Freshmen Alcohol Abuse Program reduce BAC levels among freshmen students from academic year 20012002 to academic year 2002-2003 at California State University, Chico?

\section{Review of the Literature Social Norms Theory}

Alan Berkowitz and H. Wesley Perkins became the fathers of the "social norms approach" when they first suggested it in an analysis of student drinking that showed students overestimating how much other students actually drank (Berkowitz, 2003; Perkins \& Berkowitz, 1986). This led Berkowitz and Perkins to design a new way of conducting alcohol interventions. Rather than using the conventional methods of their time, they focused on presenting actual drinking norms to students in order to align students' misperceptions with the actual norm (Perkins \& Berkowitz, 1986).

According to Berkowitz (2003), the term "social norms theory" has been the most popular term used to describe both the theory and the interventions used. The use of the social norms 
theory has grown considerably since it was first suggested in 1986. The growing body of literature is an indicator that this method has gained interest and momentum in academia.

The social norms theory is based upon the assumption that people are susceptible to adopting others' perceptions, whether or not they are true. This includes, pluralistic ignorance, the most common misperception, in which students believe that others' think, feel, and respond differently than they do, even though they may be in the majority. This relates to drinking since students who do not drink often may assume that other students drink more than they do. Students who do not drink often may start to drink in order to fit in with what is perceived to be normative to avoid potential embarrassment. Thus, the use of social norming messages gives accurate feedback to students concerning actual drinking patterns, which may reduce fear of embarrassment and worry about not fitting in.

Some people who drink to excess may think that they are in the majority. This is especially true with problem drinkers. Studies have shown that problem drinkers misperceive more than other students (Agostinelli \& Miller, 1994; Berkowitz, 2003; Pollard, Freeman, Ziegler, Hersman, \& Gross, 2000). This type of misperception is called the "false consensus effect," which is a tendency for a person to overestimate the commonality of one's behaviors (Ross, Green, \& House, 1977). Berkowitz (2003) suggests that a false uniqueness effect may also occur when a student underestimates other students' healthy behavior by believing that they are in the minority (Suls \& Wan, 1987). Non-drinkers may falsely believe that they are in the minority, thus perpetuating the misperception that drinking is the norm for the majority. Thus, social norming messages are thought to be an effective tool combating misperceptions among the non-drinking majority who believe that they are in the minority and the heavy drinking minority who think that they are in the majority (Berkowitz, 2003).

College students' misperceptions have been widely reported in a variety of studies
(Agostinelli, Brown \& Miller, 1995; Agostinelli \& Miller, 1994; Baer, 1994; Baer \& Carney, 1993; Baer, Stacy, \& Larimer, 1991; Barnett, Far, Maus, \& Miller, 1996; Beck \& Treiman, 1996; Bourgeios \& Bowen, 2001; Carter \& Kahnweiler, 2000; Clapp \& McDonnell, 2000; Fabiano, 2003; Glider, Midyett, Mills-Novoa, Johannessen, \& Collins, 2001; Haines \& Spear, 1996; Jeffrey, Negro, Demond, \& Frisone, 2003; Page, Scanlan \& Gilbert, 1999; Peeler, Far, Miller, \& Brigham, 2000; Perkins, 1985, 1987; Perkins \& Berkowitz, 1986; Perkins \& Craig, 2003a; Perkins, Meilman, Leichliter, Cashin, \& Presley, 1999; Perkins \& Wechsler, 1996; Pollard et al., 2000; Prentice \& Miller, 1993; Schroeder \& Prentice, 1998; Sher, Bartholow, \& Nanda, 2001; Steffian, 1999; Thombs, 1999, 2000; Thombs, Wolcott, \& Farkash, 1997; Werch et al., 2000). Furthermore, misperceptions are held not only by undergraduate and graduate students and even student leaders but also by various members of the campus including faculty members (Berkowitz, 1997, 2003; Berkowitz \& Perkins, 1986). Not only have misperceptions been reported on student drinking according to Berkowitz (2003), but also on the use of cigarettes, marijuana, and other illegal drugs (Haines, Barker \& Rice, 2003; Hancock \& Henry, 2003; Hansen \& Graham, 1991; Linkenbach \& Perkins, 2003; Perkins, 1985; Perkins \& Craig, 2003b; Perkins et al., 1999; Pollard et al., 2000; Wolfson, 2000).

Perkins (1997) explains that misperceptions are spread through "public conversation" by all members of a community, and problem behaviors are conversed more often than responsible behaviors that are more common but less visible. Many studies have shown that misperceptions are held by a wide variety of students. "Misperceptions have been found among fraternity members (Baer, 1994; Baer et al., 1991; Carter \& Kahnweiler, 2000; Far \& Miller, 2003; Sher et al., 2001), athletes (Thombs, 2000), student leaders (Berkowitz, 1997; Berkowitz \& Perkins, 1986), and among students of different religious backgrounds" (Berkowitz, 2003, p. 8). 
Wechsler and Kuo (2000) published a study arguing that misperceptions are not commonplace on college campuses. They claim that students accurately perceive campus norms for binge drinking (Berkowitz, 2003). However, DeJong (2000) found flaws in their study regarding their definition of binge drinking.

Perkins (2003b) noted that students envision an "average" student on campus and this perceived average may form the basis for their individual behavior. Furthermore, studies have shown that as "social distance" increases so do misperceptions. That is, most students perceive that their friends drink more than they do, and that students in general drink more than their friends (Baer, 1994; Baer et al., 1991; Beck \& Treiman, 1996; Berkowitz, 2003; Carter \& Kahnweiler, 2000; Thombs et al., 1997; Thombs, 2000). It is interesting to note that Larimer, Irvine, Kilmer \& Marlatt (1997) and Carter \& Kahnweiler (2000) have found that fraternity members accurately perceived heavy drinking of their fellow Greeks (Berkowitz, 2003). If this is the case, social norming messages in this setting may not be appropriate since this group already accurately perceives the norm.

Misperceptions have been positively correlated to drinking behavior (Beck \& Trieman, 1996; Clapp \& McDonnell, 2000; Page et al., 1999; Perkins, 1985, 1987; Perkins \& Wechsler, 1996; Thombs et al., 1997). For instance, Perkins and Wechsler (1996) found that students' perception on campus drinking was the most important variable in determining the variance in drinking behavior.

In general, the literature suggests that misperceptions exist regarding student drinking behavior. The same literature also suggests that misperceptions are the key to increased drinking and problem drinking (Berkowitz, 2003).

\section{Successful Norming Campaigns}

Several campuses have reported successful social norming campaigns with reductions in high risk drinking (Berkowitz, 2003) — Western Washington University (Fabiano, 2003), the University of Arizona (Glider et al., 2001;
Johannessen et al., 1999; Johannessen \& Glider, 2003), Northern Illinois University (Haines \& Spear, 1996; Haines \& Barker, 2003), and Hobart and William Smith Colleges (Perkins \& Craig, 2002, 2003a). Reports indicate a 20 percent or more reduction in high risk drinking at these institutions and in one case a 40 percent reduction over a four-year span (Berkowitz, 2003).

\section{Failed Social Norming Campaigns}

Failed social norming campaigns have been reported and outlined in various reports. Berkowitz (2003) noted that misperceptions may be reinforced if survey data is unreliable or confusing. He also mentions that key members of a campaign may undermine campaigns if they share their own misperceptions and negative comments about the campaigns. Some of the failed social norms campaigns consistently indicated that students did not understand the message, or the message was not believable to them (Clapp, Russell, \& DeJong, 2001).

Wechsler et al. (2003) argues that social norms campaigns downplay heavy alcohol consumption as having serious consequences to drinkers. One of the most widely cited social norms studies (Haines \& Spears, 1996) did not have a comparison group to control for other factors. Also, a higher percentage of females and younger students participated at the end of the campaign than the baseline measurement. Wechsler indicates that these two groups have been found to drink less. Furthermore, the methods used may have created a "Pygmalion effect" which may have led study participants to score higher or lower to meet the experimenters' desired outcome (Rosenthal \& Jacobson, 1968).

According to Wechsler et al. (2003) additional studies had similar methodological concerns (Glider et al., 2001; Gomberg, Schneider, \& DeJong, 2001). Also, the study by Glider et al. (2001) had an increase of funds on campus for non-alcohol social events at the same time the social norms campaign was conducted, which makes it difficult to determine whether or not the social norms campaign contributed to the decline of student drinking on campus, or 
whether it was the result of another intervention (Wechsler et al., 2003).

Wechsler et al. (2003) conducted a national evaluation of the social norms campaigns and the schools that utilized this approach. Their study did not find a decrease in student drinking among schools that used the social norms theory. According to Wechsler et al. this is because students' drinking is aligned more to their immediate social group rather than the overall student population of a school.

The social norms theory was developed at a small private college with a homogenous student population. Thus, it would make sense that there would be a decrease in student drinking. However, the social norms campaigns have been implemented in diverse school populations. "In such settings, there may be no "typical student" or single common social norm (Wechsler et al., 2003, p. 492). Furthermore, Wechsler et al. suggests further research in order to fully evaluate the effectiveness of social norms campaigns.

\section{Breath Testing}

Breath testing with a Breathalyzer ${ }^{\circledR}$ device has been used in previous studies to describe student drinking. However, in this study breath testing was used both to learn more about student drinking patterns, and by providing immediate feedback, to influence students toward less drinking in the future. Glindemann, Geller, and Ludwig's (2001) study examined university students' drinking behavior and their actual alcohol consumption. In another study Glindemann, Geller, and Fortney (1999) examined college students' self-esteem in relation to BAC level.

\section{Conclusions from the \\ Literature Review}

The results are mixed, and further research needs to be conducted to pinpoint whether or not social norms campaigns are a contributing factor in decreasing students' drinking. Certainly, other factors are involved while social norms campaigns are being conducted, thus a cause and effect relationship is not clear. Changes in the economy, an increase in non-alcoholic events on campus, stiff penalties for underage drinking on campus may all be factors in a reduction in the students' drinking behavior and actual drinking.

\section{Hypotheses}

The introduction of the Freshmen Alcohol Abuse Program is associated with a decrease in freshmen's BAC levels on CSU, Chico's campus from the academic year of 2001-2002 to 2002-2003.

\section{Methods of the Study \\ Research Design}

This study explored the relationship between increasing freshmen students' awareness of accurate drinking behavior among freshmen students through the use of social norming messages and the decrease of high-risk drinking among freshmen students. The interview used throughout the two-year program contained core questions that were utilized in this analysis (see Appendix A).

Throughout the two-year study, a social marketing campaign coined, "Did You Know," was used to influence freshmen students to align their misperceptions of alcohol consumption with the actual drinking norms. The Did You Know campaign encompassed a host of social norming tools. For example, large colorful posters were put in each residence hall and on bulletin boards throughout the campus. On each poster a social norming message was presented. The social norming messages used on the posters were based on California State University, Chico's 2000, 2001, and 2002 Core Surveys (Schafer \& Duerr, 2003). Examples of social norming messages include:

- Most CSU, Chico students drink 0-2 times per week.

- Most CSU, Chico students consume 0-5 drinks per week.

- Most CSU, Chico students drink 0-4 drinks at off-campus parties.

- Most CSU, Chico students had 4 or fewer drinks the last time they drank with other students.

- Most CSU, Chico students avoid party games. 
- Most CSU, Chico students over-estimate how much other students drink.

- At CSU, Chico, A students drink half as many drinks per week as C students. (Schafer \& Duerr, 2003).

Some posters had a list of 101 alcohol free activities in the Chico area along with community phone numbers. During the twoyear program, a total of 4,700 social norming posters were posted throughout the university (Schafer \& Duerr, 2003).

Furthermore, students who kept social norming posters in their room were awarded $\$ 5.00$ gift certificates to a restaurant near the campus or the campus bookstore. A student's dorm room had to be randomly-selected by the resident advisor in order to qualify to receive a gift certificate (Schafer \& Duerr, 2003).

Student newspaper ads were used as another channel for advertising social norming messages. A total of 60 ads were placed in the student newspaper (15 per semester) during the two-year program. The ads had the same social norming messages as the posters, and the design was similar (Schafer \& Duerr, 2003).

Screen savers were installed on several hundred workstations throughout the campus and residence halls. The screen savers included three rotating social norming messages. For those workstations that were unable to have screen savers, mouse pads with social norming messages were installed. A total of 2,000 mouse pads were made. Many of them were placed in computer labs throughout the campus, while others were sent home with interview participants of the Wanna Know campaign (Schafer \& Duerr, 2003).

Table tent cards, cards folded in the form of a pup tent, with social norming messages on them began to be used in the spring semester of 2003 . Table tent cards were placed on residence hall dining room tables in order to advertise a single social norming message. Table tent cards were rotated with new messages every two or three weeks. A total of 300 table tent cards were printed. Approximately 75 of these appeared on residence hall dining room tables at any one time (Schafer \& Duerr, 2003).

E-mails with several social norming messages were sent to all students at the beginning of the Freshmen Alcohol Abuse Program. During the December 2001 focus group concerning the Did You Know program, students stated that social norming messages received through the campuswide e-mail system were not effective. Consequently, this program was discontinued (Schafer \& Duerr, 2003).

T-shirts with social norming messages written on them were a popular item in the Freshmen Alcohol Abuse Program. A total of 1,973 tshirts were printed with "Most CSU, Chico students underestimate how much other students drink" written on the back. On the front of the tshirt the chemical formula for alcohol was printed along with the Wanna Know logo. These t-shirts were given to interview participants of the Wanna Know campaign. Later in the program another t-shirt was designed for students who had participated in the Wanna Know interview and had a BAC level of .000. On the front of the t-shirt it read, "How low can you blow?". The back read "I blew .00." Approximately 450 of these t-shirts were printed for participants of the Wanna Know interview and alcohol breath test who tested .000 on their breath test (Schafer \& Duerr, 2003, p. 4).

Participants of the Wanna Know study were given the option to choose a water bottle rather than a t-shirt. A total of 1,050 water bottles were distributed that had the Wanna Know logo and the message, "Most CSU, Chico students overestimate how much other students drink" (Schafer \& Duerr, 2003, p. 4).

Furthermore, a total of 3,200 brochures were printed and handed out to Wanna Know interview participants and distributed around campus. Each brochure contained social norming messages (Schafer \& Duerr, 2003).

The Campus Alcohol Education Center (CADEC) helped promote social norming messages for the Freshmen Alcohol Abuse Program. These include presentations to the 
new parents and students. The former University President Manual Esteban also mentioned social norming messages during his speeches to new students (Schafer \& Duerr, 2003).

Data were collected during the academic years of 2001-2002 to 2002-2003 for the Wanna Know component of the Freshmen Alcohol Abuse Program that included an interview and alcohol breath test. The program had two test nights in September 2001 and began actual data collecting in October 2001. Freshmen students were selected and interviewed on unannounced "partying nights" 12 nights a semester for two years (Thursday, Friday, and Saturday) from
10:30 PM to 2:30 AM on campus and offcampus residential halls. Students' who approached the Wanna Know team were not allowed to participate in the study. The study was conducted on unannounced "partying nights" in order to minimize students from drinking to score high on the alcohol breath test. The notion that students may drink to score high is supported in the literature where, "...immediate breath analysis feedback can actually encourage excessive drinking when students make a contest of achieving high BACs" (“Task Force,” 2002, p. 24). The dates the data were collected are listed in Tables 1- 2.

Table 1

Month and Date of Data Collection for the Freshmen Alcohol Abuse Program at CSU, Chico for the Academic Year 2001-2002

\begin{tabular}{|l|l|}
\hline \multicolumn{1}{|c|}{ Month } & \multicolumn{1}{c|}{ Date } \\
\hline October & $5,6,11,19,20,25$ \\
\hline November & 3,29 \\
\hline December & $1,6,8,14$ \\
\hline February & 15 \\
\hline March & 2,7 \\
\hline April & $4,5,12,13,18,19,25,27$ \\
\hline May & $3,4,10,11$ \\
\hline
\end{tabular}

Note. From “Social Norming and Breath Sampling: Preventing High-Risk Drinking Among First-Year Students,” by W. E. Schafer, and M. Duerr, 2003, pp. 5-6.

Table 2

Month and Date of Data Collection for the Freshmen Alcohol Abuse Program at CSU, Chico for the Academic Year 2002-2003

\begin{tabular}{|l|l|}
\hline \multicolumn{1}{|c|}{ Month } & \multicolumn{1}{c|}{ Date } \\
\hline September & $6,12,13,26,28$ \\
\hline October & $4,10,25,26$ \\
\hline November & 1,2 \\
\hline December & 6 \\
\hline January & 31 \\
\hline February & 6,28 \\
\hline March & $7,27,29$ \\
\hline April & $4,10,11,18,26$ \\
\hline May & $2,3,9$ \\
\hline
\end{tabular}

Note. From “Social Norming and Breath Sampling: Preventing High-Risk Drinking Among First-Year Students,” by W. E. Schafer, and M. Duerr, 2003, pp. 5-6. 
Three teams of one registered nurse and two trained undergraduate students were stationed along common routes where students typically walk on their way home to their residence halls. One team member approached a student at fourminute intervals to ask for voluntary participation in the interview and alcohol breath test. Only freshmen students 18 years or older were allowed to participate. After the interview and alcohol breath test, each participant was given their BAC level, a social norming packet, an information card that described the project, a handout on the voluntary nature of their participation, telephone number of CADEC, alcohol poisoning information, and legal information related to alcohol consumption. During the first semester, the entire interview and alcohol breath test took approximately seven minutes. However, after the first semester the interview was shortened to four minutes (Schafer \& Duerr, 2003).

In the first year of data collection, the Wanna Know campaign completed 1,419 interviews and alcohol breath tests. However, 105 interviews were discarded since participants were later determined not to be freshmen students. The Project Director, in order to increase the likelihood that the participants were freshmen, decided that the second semester interviews would only include students who were 18 or 19 years of age. After the adjustments, a total of 1,314 interviews were used for the first year. In the second year of data collection, a total of 1,215 interviews and alcohol breath tests were conducted (Schafer \& Duerr, 2003).

Outliers were removed from the data set for the variable "number of drinks," for those students who self reported that they drank 20 or more drinks. Only a small percent actually reported 20 or more drinks.

\section{Strengths and Weaknesses}

During the Wanna Know component of the Freshmen Alcohol Abuse Program one in six students turned down a chance to be interviewed and have an alcohol breath test (Schafer \& Duerr, 2003). Further weaknesses may have involved under-sampling of nondrinkers and over-sampling drinkers since those who were less likely to drink tended to stay home, and those who drank stayed out late at night. "It should be noted that findings for these students are likely to indicate that the "Wanna Know" sample - selected from students coming back to their dorm room late at night — is not representative of the general population of CSU, Chico freshmen” (Schafer \& Duerr, 2003, p. 7).

During the first semester, many students over age 20 were sampled, a possible indication that they were not freshmen students. This error may have occurred if team members admitted students into the study in order to fulfill that night's quota, mistakenly admitted nonfreshmen, or participants may have lied about their class. To address this issue, students who were 20 years old or over were removed from the study, and in 2002 team members were instructed to admit students who were 18 or 19 years of age (Schafer \& Duerr, 2003). Furthermore, "It is imperative, of course, that these findings be viewed with caution in that a number of simultaneous programs and policies were in place on this campus during the two years of the project that might also have influenced measured outcomes" (Schafer \& Duerr, 2003, p. 7).

\section{Sampling Technique}

The sampling technique used in this study was a "convenience sample" despite the study using time intervals to choose student participants. Wanna Know stations were set-up around campus to sample readily available student participants, rather than seeking out all members of the freshman population. Since not all members of the study population were out on data collection nights, the elements within the target population did not have an equal chance of being selected. Hence, inferences cannot be made from the sample to the study population. However, a descriptive analysis of what happened on those nights concerning those freshmen who participated in the study is appropriate (Triola, 1995).

\section{Alcohol Breath Test}

Subjects were administered an alcohol breath test with an Alco-Sensor IV Breathalyzer ${ }^{\circledR}$ device (Intoximeters, Inc., St. Louis, MO) that 
took samples of deep lung breath and displayed the results in a three-digit readout. The linear range of the Breathalyzer ${ }^{\circledR}$ device could accurately detect breath alcohol between .000 to .400 BrAC. In addition, an approved dry gas standard was used and supplied by Intoximeters to calibrate the Alco-Sensor IVs Breathalyzer ${ }^{\circledR}$ device. Only the supervising nurse was allowed to calibrate the Breathalyzer ${ }^{\circledR}$ devices. When properly calibrated the instruments maintained an accuracy of \pm .005 at the .100 level for several months at a time. This means that once it is calibrated at the .100 level the Breathalyzer ${ }^{\circledR}$ device will reject readings that are above .105 and below .95. The instruments were also able to operate from $0^{\circ}$ to $40^{\circ}$ Celsius, and had a mouthpiece release feature which eliminated contact with a used mouthpiece (“Alco-Sensor IV,” 2004).

\section{Interview}

The interview had a cover page that consisted of a check-list designed to find out some basic information about the test subjects. The date, time, interviewer, and alcohol breath test number were also recorded. Furthermore, the question on the check-list page, "is subject a freshman” was pertinent to the research project, since only freshman students were being targeted for this study. "Is subject heading home" for the night assessed whether the student was continuing their nighttime activities, or if the student was heading back to their residence hall for the rest of the evening. The question, "did you take the subject away from the group" assessed if students were walking with friends and were removed from their group in order to participate in the study. This question also observed if they were walking alone. The rest of the questions on the subject check-list were posed to the interviewer in order to help them remember the procedure.

The students' sex was asked in order to quantify what sex had the highest BAC level, and examine the relationship between sex and what type of drink each sex generally consume. Freshmen students were also asked in which residence hall they lived. The list of residence halls included: Whitney, Mechoopda, Esken, Lassen, Shasta, University Village, and Craig
Hall. Furthermore, students were asked in the interview if they have had an alcohol breath test before. This question was not asked in year one so comparisons cannot be made.

Another interesting question posed in the interview was, "at what age did you have your first drink." Unfortunately, comparisons cannot be made from year one and year two data since this question was only added in the second year.

The question was, "before attending CSU, Chico, did you drink more, less, the same as you do now." The question was designed to assess if the college atmosphere was a contributing factor in freshmen students' drinking behaviors. Again, this question was not used in the first year of data collection so comparisons cannot be made.

The question, "have you had any alcoholic beverages today" was important to assess if students were drinking or not drinking when they were out on Thursday, Friday, and Saturday nights. If students had been drinking then they were asked what type of drink and how many. The categories for type of drink included: beer, wine, liquor, and combination. Students who had been drinking were asked what time they began drinking. Also, they were asked what time they had stopped drinking. If students were not finished drinking the interviewers would ask them what time they last consumed an alcoholic beverage.

The question "what is your approximate weight" was asked in order to observe the relationship between their weight, BAC level, and number of drinks. Students were asked how much money they spent on alcohol for themselves. Comparisons can be made of the mean and median amount of money spent from year one and year two. Also, students were asked "where did you obtain your drinks today" on the particular night that they were being interviewed. The exhaustive list includes: at an open party (not sorority or fraternity), at a fraternity or sorority, at a friend's residence, at a store, at a bar, in a residence hall, outside a residence hall, in my own home or room, at my parent's home, and other. 
On the last page of the interview students were asked what they thought their BAC level was prior to receiving their actual BAC level. This question is important since it will assess the students' perceptions of their drinking behavior, and to evaluate if they misperceive or not. After students stated their BAC level estimate to the interviewer the alcohol breath test was administered by means of a Breathalyzer ${ }^{\circledR}$ device. While this process was occurring the student's friend (if available) was asked what their perception of their friend's BAC level was. This is to evaluate if students' misperceive others' BAC level. This question was not created until year two so comparisons of year one to year two data cannot be made.

The students who participated in the study were asked "how many drinks do you think most CSU, Chico students consume at off-campus parties" in order to evaluate if students' misperceive how much other students' drink. After the student was finished with the interview they were given this social norming message: "Our most recent random-sample survey of over 800 CSU, Chico students in spring 2001 showed that most students over-estimate how much other students drink. In fact, most CSU, Chico students consume between 0-4 drinks at offcampus parties." Students were thanked for participating, given a brochure, BAC level chart, t-shirt or water bottle, and for those students who blew a .000 received a gift certificate.

\section{Data Analysis}

The data were originally processed by Duerr Evaluation with a computer program called Statview ${ }^{\circledR}$. Statview ${ }^{\circledR}$ is no longer available. Therefore, the raw data from Statview was imported into (Statistical Package for the Social Sciences) SPSS ${ }^{\circledR}$ 11.0.1 for the purposes of data analysis. Descriptive statistics were calculated for the analysis.

\section{Results}

\section{Sex Composition}

In terms of sex composition, the students sampled in this study were fairly consistent from year one to year two. In the first year of the study (2001 to 2002) of those CSU, Chico freshmen students interviewed, 55.5 percent were males and 44.5 percent were females, a difference of 11.0 percentage points. In the second year of the study (2002 to 2003) of those interviewed, 56.2 percent were males and 43.8 percent were females, a difference of 12.4 percentage points (see Table 3 ). The sample differed somewhat from the overall sex composition of the university. For example, in fall 2002 the percentage of all the CSU, Chico freshmen males and females was 44 percent and 56 percent, respectively. In spring 2003 the percentage of freshmen males and females was 45 percent and 55 percent, respectively (“Institutional Research,” 2004).

Table 3

Percentage of CSU, Chico Freshmen Student Participants by Year and Sex

\begin{tabular}{|c|c|c|}
\hline & \multicolumn{2}{|c|}{ Percent Year } \\
\hline Sex & $2001-2002^{\mathrm{a}}$ & $2002-2003^{b}$ \\
\hline Male & 55.5 & 56.2 \\
\hline Female & 44.5 & 43.8 \\
\hline Total $^{\mathrm{C}} \%$ & 100.0 & 100.0 \\
\hline
\end{tabular}

Note. ${ }^{a} \underline{n}=1308 .{ }^{b} \underline{n}=1212 .{ }^{c} \underline{n}=2520$. 


\section{Mean Blood Alcohol Concentration}

The mean BAC level for all the CSU, Chico freshmen students interviewed who had received a breath test for the first year was .068 and .056 in the second year with standard deviations of .06 each year. From year one and year two there was a drop in BAC levels of .012, which represents a 21.4 percent decline (see Table 4). BAC levels in year one varied from a low of .000 to a high of .241 or a range of .241. BAC levels in year two varied from a low of .000 to a high of .288 or a range of .288. Thus the range increased by .047 BAC between years one and two.
Realizing that the overall distribution would be affected by the number of individuals with .000 BAC levels, these individuals were eliminated from the analysis to determine BAC levels for those individuals with levels above .000. The mean BAC level for those CSU, Chico freshmen who had been drinking in the first year was .091 with a standard deviation of .05. Similarly, in the second year, the mean BAC level was .087 with a standard deviation of .05 , a decline of .004 BAC for the two years in question or a 4.6 percent decline (see Table 5). BAC levels in year one for those who had been drinking varied from a low of .006 to a high of .241 or a range of .235. BAC levels in year two varied from a low of .006 to a high of .288 or a range of .282.

Table 4

Mean Blood Alcohol Concentration (BAC) of CSU, Chico Freshmen Students by Year

\begin{tabular}{|c|c|c|}
\hline Year & Mean BAC & SD \\
\hline $2001-2002$ & $.068^{\mathrm{a}}$ & .06 \\
\hline $2002-2003$ & $.056^{\mathrm{b}}$ & .06 \\
\hline
\end{tabular}

Table 5

Mean Blood Alcohol Concentration (BAC) of Those CSU, Chico Freshmen Students Drinking by Year

\begin{tabular}{|c|c|c|c|c|}
\hline Year & & Mean BAC & & SD \\
\hline $2001-2002$ & & $.091^{\mathrm{a}}$ & & .05 \\
\hline $2002-2003$ & & $.087^{\mathrm{b}}$ & & .05 \\
\hline
\end{tabular}

Note. ${ }^{\mathrm{a}} \underline{\mathrm{n}}=974 .{ }^{\mathrm{b}} \underline{\mathrm{n}}=788$.

Realizing from the review of the literature that there are differences in drinking patterns between males and females, the data were analyzed to note these differences. The mean BAC levels for those CSU, Chico students interviewed by sex for year one was .075 for males and .058 for females, a difference of .017 BAC. BAC levels dropped in year two for both males and females - .064 for males and .047 for females or a difference of .017 BAC (see
Table 6). BAC levels in year one varied from a low of .000 for both males and females to a high of .241 and .215 BAC for the males and females, respectively. The range in year one was .241 for males and .215 for females. BAC levels in year two varied from a low BAC level of .000 for both males and females to a high of .288 and .269 for males and females, respectively. The range for the males and females in year two was .288 and .269 BAC, respectively. 
Table 6

Mean Blood Alcohol Concentration (BAC) of CSU, Chico Freshmen Students by Year and Sex

\begin{tabular}{|c|c|c|}
\hline & \multicolumn{2}{|c|}{ Sex } \\
\hline Year & Male & Female \\
\hline $2001-2002$ & $.075^{\mathrm{a}}$ & $.058^{\mathrm{b}}$ \\
\hline $2002-2003$ & $.064^{\mathrm{c}}$ & $.047^{\mathrm{d}}$ \\
\hline
\end{tabular}

It was important to examine sex differences while eliminating those individuals with .000 BAC levels. The mean BAC levels of those CSU, Chico freshmen students who had been drinking was .093 for males and .088 for females. In year two, the BAC levels dropped to .090 for males and .082 for females, or 3.3 and 7.3 percent, respectively (see Table 7). BAC levels in year one varied from a low of .006 for the males to a high of .241 or a range of .235 BAC. For females BAC levels in year one varied from a low of .006 to a high of .215 or a range of .209 BAC. BAC levels varied in year two from a low of .006 for the males to a high of
.288 or a range of .282 BAC. BAC levels in year two varied from a low of .006 to a high of .269 or a range of .263 BAC.

Major changes were noted in the percentage of CSU, Chico freshmen interviewed who tested .000 BAC level from year one to year two. In year one, 25.5 percent of those interviewed had a .000 BAC level, while in year two 35.0 percent had a .000 BAC level, a 9.5 percentage point difference or a 37.3 percent increase in those students with a .000 BAC level (see Table 8).

Table 7

Mean Blood Alcohol Concentration (BAC) of Those CSU, Chico Freshmen Students Drinking by Year and Sex

\begin{tabular}{|l|c|c|}
\hline & \multicolumn{2}{|c|}{ Sex } \\
\hline Year & Male & Female \\
\hline $2001-2002$ & $.093^{\mathrm{a}}$ & $.088^{\mathrm{b}}$ \\
\hline $2002-2003$ & $.090^{\mathrm{c}}$ & $.082^{\mathrm{d}}$ \\
\hline
\end{tabular}

Note. ${ }^{\mathrm{a}} \underline{\mathrm{n}}=$ 581. ${ }^{\mathrm{b}} \underline{\mathrm{n}}=387 .{ }^{\mathrm{c}} \underline{\mathrm{n}}=$ 483. ${ }^{\mathrm{d}} \underline{\mathrm{n}}=302$.

Table 8

Percentage of CSU, Chico Freshmen Students Who Had a .000 Blood Alcohol Concentration (BAC) by Year

\begin{tabular}{|c|c|}
\hline Year & Percent of .000 \\
\hline $2001-2002$ & $25.5^{\mathrm{a}}$ \\
\hline $2002-2003$ & $35.0^{\mathrm{b}}$ \\
\hline
\end{tabular}

Note. ${ }^{\mathrm{a}} \underline{\mathrm{n}}=1308 .{ }^{\mathrm{b}} \underline{\mathrm{n}}=1213$. 
The percentage of those CSU, Chico freshmen interviewed who had a .080 BAC level (legally drunk by California standards) or above in year one was 57.6 percent and 52.4 percent in year two (see Table 9). Thus, in both years a majority of the freshmen that had been drinking were legally drunk.

Differences were noted between males and females with .000 BAC levels between year one and year two. In year one, 19.4 percent of the males and 33.4 percent of the females had a .000 BAC level, a difference of 14.0 percentage points. In year two, the percentages were 29.0 percent of the males and 43.0 percent of the females, a difference of 14.0 percentage points between males and females (see Table 10).

\section{Mean Number of Drinks}

he mean number of drinks for the evaluation period (the evaluation period ranged from the time the respondent got up until the interview process ended at 2:30 AM) of those CSU, Chico freshmen who were interviewed was 5.8 drinks in both years one and two with a standard deviation of 3.6 and 3.4, respectively (see Table 11). In both years the number of drinks ranged in year one and year two from a low of 0 to a high of 20.

Table 9

Percentage of Those CSU, Chico Freshmen Who Had Been Drinking Who Had a Blood Alcohol Concentration (BAC) of $.080^{\mathrm{a}}$ or Above

\begin{tabular}{|c|c|c|}
\hline Year & & Percentage \\
\hline $2001-2002$ & & $57.6^{\mathrm{b}}$ \\
\hline $2002-2003$ & & $52.4^{\mathrm{C}}$ \\
\hline
\end{tabular}

Note. ${ }^{\mathrm{a}} .080 \mathrm{BAC}$ level is legally drunk for those 21 years and above in California. A BAC level above .000 is illegal for those under $21 .{ }^{b} \underline{n}=974$. ${ }^{c} \underline{n}=788$.

Table 10

Percentage of CSU, Chico Freshmen Students Whose Blood Alcohol Concentration (BAC) Was .000 by Year and Sex

\begin{tabular}{|l|c|c|c|c|}
\hline & & \multicolumn{3}{|c|}{ Percent Year } \\
\hline \multicolumn{1}{|c|}{ Sex } & & $\mathbf{2 0 0 1 - 2 0 0 2}$ & & $\mathbf{2 0 0 2 - 2 0 0 3}$ \\
\hline Male & & $19.4^{\mathrm{a}}$ & & $29.0^{\mathrm{b}}$ \\
\hline Female & & $33.4^{\mathrm{c}}$ & & $43.0^{\mathrm{d}}$ \\
\hline
\end{tabular}

Note. ${ }^{\mathrm{a}} \underline{\mathrm{n}}=140 .{ }^{\mathrm{b}} \underline{\mathrm{n}}=197 .{ }^{\mathrm{c}} \underline{\mathrm{n}}=194 .{ }^{\mathrm{d}} \underline{\mathrm{n}}=228$.

Table 11

Mean Number of Drinks of CSU, Chico, Freshmen Students by Year

\begin{tabular}{|c|c|c|c|c|}
\hline Year & & Drinks & & SD \\
\hline $2001-2002^{\mathrm{a}}$ & & 5.8 & & 3.6 \\
\hline $2002-2003^{\mathrm{b}}$ & & 5.8 & & 3.4 \\
\hline
\end{tabular}

Note. ${ }^{a} \underline{n}=1149 .{ }^{b} \underline{n}=877$. 
Limiting the analysis to the CSU, Chico freshmen who had been drinking, resulted in a mean of 6.4 drinks in year one and 5.8 in year two with a standard deviation of 3.2 and 3.4, respectively. This is a difference of 0.6 drinks for year one and year two (see Table 12). The number of drinks varied in year one and year two from a low of 1 to a high of 20 or a range of 19.

In both year one and year two the mean number of drinks of all the CSU, Chico freshmen students interviewed were 6.6 drinks for males and 4.6 for females, a difference of 2.0 drinks. In other words, males drank 2.0 drinks more than the females both years (see Table 13).

The number of drinks varied in year one from a low of 0 for males to a high of 20 or a range of 20. In year one, the low for females was 0 to a high of 18 or range of 18 . The number of drinks varied in year two from a low of 0 for males to a high of 20 or a range of 20. In year two, the low for females was 0 to a high of 18 or a range of 18.

Table 12

Mean Number of Drinks of CSU, Chico Freshmen Students Who Had Been Drinking by Year

\begin{tabular}{|c|c|c|c|c|}
\hline Year & & Drinks & & SD \\
\hline $2001-2002^{\mathrm{a}}$ & & 6.4 & & 3.2 \\
\hline $2002-2003^{\mathrm{b}}$ & & 5.8 & & 3.4 \\
\hline
\end{tabular}

Note. $\underline{a} \underline{\mathrm{a}}=1030 .{ }^{\mathrm{b}} \underline{\mathrm{n}}=875$.

Table 13

Mean Number of Drinks of All CSU, Chico Freshmen Students Interviewed by Year and Sex

\begin{tabular}{|c|c|c|c|}
\hline \multicolumn{1}{|c|}{ Year } & \multicolumn{3}{|c|}{ Sex } \\
\hline $2001-2002$ & Male & & Female \\
\hline $2002-2003$ & $6.6^{\mathrm{a}}$ & & $4.6^{\mathrm{b}}$ \\
\hline
\end{tabular}

Note. ${ }^{\mathrm{a}} \underline{\mathrm{n}}=664 .{ }^{\mathrm{b}} \underline{\mathrm{n}}=479 .{ }^{\mathrm{c}} \underline{\mathrm{n}}=525 .{ }^{\mathrm{d}} \underline{\mathrm{n}}=349$.

Again, limiting the analysis to those students who had been drinking the mean number of drinks was 7.2 for males and 5.3 for females in year one, a difference of 1.9 drinks (see Table 14). The number of drinks varied in year one from a low of 1 for males to a high of 20 or a range of 19 . In year one, the low for females was 1 to a high of 18 or range of 17 .

In year two, the mean number of drinks was 6.6 for males and 4.7 for females, a difference of 1.9 drinks. Males in the sample definitely drank more than females. However, there was a decline in the mean number of drinks between year one and year two for both males and females - 7.2 to 6.6 drinks for males or a 9.4 percent decline and 5.3 to 4.7 drinks for females or a 12.8 percent decline (see Table 14). The number of drinks varied in year two from a low of 1 for males to a high of 20 or a range of 19 . In year two, the low for females was 1 to a high of 18 or a range of 17. 
Table 14

Mean Number of Drinks of Those CSU, Chico Freshmen Students Drinking by Year and Sex

\begin{tabular}{|l|c|c|c|c|}
\hline & & \multicolumn{3}{|c|}{ Sex } \\
\hline Year & & Male & & Female \\
\hline $2001-2002$ & & & & \\
\hline & & $7.2^{\mathrm{a}}$ & & $5.3^{\mathrm{b}}$ \\
\hline $2002-2003$ & & & & \\
\hline
\end{tabular}

Note. $\underline{a} \underline{n}=605 .{ }^{b} \underline{n}=419 .{ }^{c} \underline{n}=525 . ~{ }^{d} \underline{n}=347$.

\section{Mean Number of Hours and} Minutes Spent Drinking

Data were collected and analyzed on the mean number of hours spent drinking during the evaluation period. The mean number of hours and minutes CSU, Chico freshmen students had been drinking during the evaluation period in year one was 3 hours and 12 minutes for males and 2 hours and 33 minutes for females, a difference of 39 minutes. Hence, of those sampled males in the sample tended to drink longer than females in year one, however, the difference narrowed in year two. In year two the mean number of hours and minutes was 3 hours and 13 minutes for males and 2 hours and 15 minutes for females, a difference of 18 minutes (see Table 15).

The number of minutes CSU, Chico freshmen drank varied in year one from a low of 1 minute for males to a high of 16 hours and 0 minutes or a range of 15 hours and 59 minutes. In year one, the low for females was 1 minute to a high of 16 hours and 0 minutes or a range of 15 hours and 59 minutes. In year two, the low for males was 1 minute to a high of 13 hours and 15 minutes or a range of 13 hours and 14 minutes. The low for females was 0 minutes to a high of 14 hours and 0 minutes or a range of 14 hours and 0 minutes.

In year one, the mean high hours and minutes CSU, Chico freshmen students had been drinking was 3 hours and 32 minutes in Mechoopda Hall and the low was 1 hour and 31 minutes in Konkow Hall, a range of 1 hour and 43 minutes. In year two, the high hours and minutes was 4 hours and 39 minutes in Craig Hall and the low was 2 hours and 38 minutes in Shasta Hall, a range of 2 hours and 1 minute.

Table 15

Mean Number of Hours and Minutes CSU, Chico Freshmen Students Had Been Drinking by Year and Sex

\begin{tabular}{|c|c|c|c|}
\hline & \multicolumn{2}{|c|}{ Sex } & \\
\hline Year & Male & Female & Total \\
\hline 2001-2002 & $3: 12^{\mathrm{a}}$ & $2: 33^{b}$ & $5: 45^{c}$ \\
\hline $2002-2003$ & $3: 13^{d}$ & $2: 15^{\mathrm{e}}$ & $5: 28^{f}$ \\
\hline
\end{tabular}

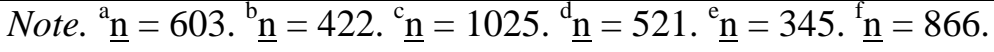


In year one, the top three residences with the highest mean number of hours and minutes drinking were Mechoopda Hall, Esken Hall, and Whitney Hall in descending order. In year two the top three were Craig Hall, University Village, and Konkow Hall in descending order (see Table 16). There was not a major pattern from year one and year two with some halls increasing dramatically or decreasing and some did not change.

\section{Sex and Type of Drink}

There were consistent patterns in drinking preferences for males and females during both periods under consideration. Males preferred beer, combination drinks, and liquor while females preferred liquor, combination, and beer (see Table 17).

Preferences for various types of alcoholic beverages between males and females are clearly illustrated in 2002-2003 where 49.2 percent of the males compared to 31.1 percent of the females reported drinking beer. However, 35.7 percent of the females compared to 18.1 percent of the males reported to drinking liquor.

Similar percentages roughly 31.0 percent of males and females reported drinking combination drinks. Few males and females reported drinking wine, 2.9 percent for females and 0.2 for males in 2002-2003 (see Table 17).

Table 16

Mean Number of Hours and Minutes CSU, Chico Freshmen Students Had Been Drinking by Year and Residency

\begin{tabular}{|l|c|c|}
\hline & \multicolumn{2}{|c|}{ Year } \\
\hline Residence Hall & $\mathbf{2 0 0 1 - 2 0 0 2}^{\mathbf{a}}$ & $\mathbf{2 0 0 2 - 2 0 0 3}^{\mathbf{b}}$ \\
\hline Craig Hall & $3: 02$ & $4: 39$ \\
\hline Esken Hall & $3: 14$ & $2: 48$ \\
\hline Konkow Hall & $1: 31$ & $3: 17$ \\
\hline Lassen Hall & $2: 31$ & $2: 39$ \\
\hline Mechoopda Hall & $3: 32$ & $2: 48$ \\
\hline Shasta Hall & $2: 17$ & $2: 38$ \\
\hline University Village & $2: 01$ & $3: 53$ \\
\hline Whitney Hall & $3: 07$ & $2: 43$ \\
\hline
\end{tabular}

Note. ${ }^{a} \underline{n}=849 .{ }^{b} \underline{n}=808$.

Table 17

Sex and Type of Drink of CSU, Chico Freshmen Students for 2001-2002 to 2002-2003

\begin{tabular}{|l|c|c|c|c|}
\hline & \multicolumn{4}{|c|}{$\%$ Sex } \\
\hline & \multicolumn{2}{|c|}{ Male } & \multicolumn{2}{c|}{ Female } \\
\hline Type of Drink & $\mathbf{2 0 0 1 - 2}^{\mathbf{a}}$ & $\mathbf{2 0 0 2 - 3}^{\mathbf{b}}$ & $\mathbf{2 0 0 1 - 2}^{\mathbf{c}}$ & $\mathbf{2 0 0 2 - 3}^{\mathbf{d}}$ \\
\hline Beer & 48.2 & 49.2 & 25.8 & 31.1 \\
\hline Combination & 31.5 & 32.4 & 31.7 & 30.3 \\
\hline Liquor & 19.1 & 18.1 & 41.6 & 35.7 \\
\hline Wine & 1.2 & 0.2 & 0.9 & 2.9 \\
\hline Total \% & 100.0 & 99.9 & 100.0 & 100.0 \\
\hline
\end{tabular}

Note. ${ }^{a} \underline{n}=606 .{ }^{b} \underline{n}=524 . ~{ }^{c} \underline{n}=423 .{ }^{d} \underline{n}=347$. 


\section{Mean Dollars Spent}

The amount of money spent per evaluation period was of interest. The mean dollars spent by those CSU, Chico freshmen who had been drinking was $\$ 6.40$ for males and $\$ 3.77$ for females, a difference of $\$ 2.63$. In year two, the mean amount spent dropped for both males and females and stood at $\$ 5.44$ and $\$ 3.48$, respectively, a difference of $\$ 1.96$ (see Table 18). The mean dollars spent during an evaluation period varied from a low of $\$ 0.00$ dollars to a high of $\$ 150.00$ for both males and females or range of $\$ 150.00$. In year two, the low was $\$ 0.00$ for males and females to a high of $\$ 240.00$ and $\$ 180.00$, respectively.

It is clear from an analysis of the data that males spent more money on alcohol than females for each evaluation period. In addition, it should be noted that there was a drop in the amount of money spent between year one and year two for both males and females, declining 17.6 percent and 8.3 percent, respectively.

\section{Drinking the Day of the Evaluation}

The percentage of the individuals interviewed who were drinking the day of the interview was of interest. In year one, the percentage of male CSU, Chico freshmen students reporting "yes" to drinking the day of the interview was 84.6 percent and 73.4 percent for females, a difference of 11.2 percentage points. In year two, the percentage of males reporting "yes" to drinking the day of the interview was 77.1 percent and 65.2 percent for females, or a difference of 11.9 percentage points (see Table 19). Clearly, the majority of students interviewed during the evaluation had been drinking. However, there was a drop in the percentage of those drinking between year one and year two for males and females, 9.7 and 12.6 percent, respectively.

Table 18

Mean Dollars Spent on Alcohol by Those CSU, Chico Students for Each Evaluation Period Who Had a Blood Alcohol Concentration (BAC) Above .000 by Year and Sex

\begin{tabular}{|c|c|c|c|}
\hline & & \multicolumn{2}{|c|}{ Sex } \\
\hline Year & & Male & Female \\
\hline & & & \\
\hline $2001-2002$ & & $6.40^{\mathrm{a}}$ & $3.77^{\mathrm{b}}$ \\
\hline & & & \\
\hline $2002-2003$ & & $5.44^{\mathrm{c}}$ & $3.48^{\mathrm{d}}$ \\
\hline
\end{tabular}

Note. $\underline{a} \underline{\mathrm{n}}=571 .{ }^{\mathrm{b}} \underline{\mathrm{n}}=382 .{ }^{c} \underline{\mathrm{n}}=478 .{ }^{\mathrm{d}} \underline{\mathrm{n}}=298$.

Table 19

Percentage of CSU, Chico Freshmen Students’ Reporting Yes to Drinking the Day of the Evaluation Period by Year and Sex

\begin{tabular}{|l|c|c|c|c|}
\hline & & \multicolumn{3}{|c|}{ Percent Sex } \\
\hline Year & & Male & & Female \\
\hline $2001-2002$ & & $84.6^{\mathrm{a}}$ & & $73.4^{\mathrm{b}}$ \\
\hline $2002-2003$ & & $77.1^{\mathrm{c}}$ & & $65.2^{\mathrm{d}}$ \\
\hline
\end{tabular}

Note. ${ }^{a} \underline{n}=721 .{ }^{b} \underline{n}=580 .{ }^{c} \underline{n}=680 .{ }^{d} \underline{n}=529$. 


\section{Where Students' \\ Obtained Their Drinks}

The source of alcohol for CSU, Chico freshmen students was of interest and varied from year one and year two. In year one, the top five sources of alcohol were friend's residence, open party, store-self, store-someone else, and residence hall in descending order. In year two, the top five sources of alcohol were friend's residence, store-someone else, open party, outside residence hall, and residence hall in descending order. From the data obtained it was clear that the major source of alcohol was from a friend's residence for both years one and year two. Obtaining alcohol from an open party moved from second place to third place. Storesomeone else moved from third to second place and store-self was third in year one and did not place in year two. Students who obtained alcohol outside residence hall was not ranked in year one, but made it to fourth place in year two (Table 20). Overall, the students mainly relied on their friends and open parties to obtain alcohol.

Table 20

Percentage of Where CSU, Chico Freshmen Students' Obtained Their Alcohol by Year

\begin{tabular}{|l|c|c|}
\hline & \multicolumn{2}{|c|}{ Percent Year } \\
\hline \multicolumn{1}{|c|}{ Obtained Drinks $^{\mathrm{and}}$} & $\mathbf{2 0 0 1 - 2 0 0 2}$ & $\mathbf{2 0 0 2 - 2 0 0 3}$ \\
\hline Open Party $^{\mathrm{a}}$ & 14.6 & 26.4 \\
\hline Fraternity/Sorority $^{\mathrm{b}}$ & 7.4 & 13.1 \\
\hline Friend's Residence $^{\mathrm{c}}$ & 41.3 & 38.9 \\
\hline Store-Self $^{\mathrm{d}}$ & 14.4 & 5.6 \\
\hline Store-Someone Else $^{\mathrm{e}}$ & 12.5 & 31.9 \\
\hline Bar-Self $^{\mathrm{f}}$ & 4.0 & 0.7 \\
\hline Bar-Someone Else $^{\mathrm{g}}$ & 0.4 & 0.7 \\
\hline Residence Hall $^{\mathrm{h}}$ & 9.1 & 13.7 \\
\hline Outside Residence Hall $^{\mathrm{i}}$ & 8.4 & 18.3 \\
\hline In Home $^{\mathrm{R}}$ Room $^{\mathrm{j}}$ & 3.1 & 4.1 \\
\hline Parent's Home $^{\mathrm{k}}$ & 0.5 & 0.2 \\
\hline
\end{tabular}

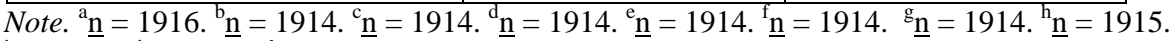
$\underline{\mathrm{i}} \underline{\mathrm{i}}=1914 . \underline{\mathrm{n}}=1914 \cdot{ }^{\mathrm{k}} \underline{\mathrm{n}}=1914$.

\section{Residence Halls}

The mean BAC levels for those CSU, Chico freshmen drinking during the evaluation period by residency varied from year one to year two. Mechoopda had the highest BAC levels with .100 and .099 for year one and year two, respectively. Craig Hall and Shasta Hall were in second place in year one and year two, respectively. Whitney Hall was in third place in year one and Esken Hall and University Village tied for third in year two. Lassen Hall and Whitney Hall were in fourth place in year one and year two, respectively. Finally, Esken Hall and Craig Hall were in fifth place in year one and year two, respectively (see Table 21). 
Table 21

Mean Blood Alcohol Concentration (BAC) of CSU, Chico Freshmen Students Who Had Been Drinking by Year and Residency

\begin{tabular}{|l|c|c|}
\hline & \multicolumn{2}{|c|}{ Year } \\
\hline Residence Hall & $\mathbf{2 0 0 1 - 2 0 0 2}^{\mathbf{a}}$ & $\mathbf{2 0 0 2 - 2 0 0 3}^{\mathbf{b}}$ \\
\hline Craig Hall & .100 & .082 \\
\hline Esken Hall & .088 & .087 \\
\hline Konkow Hall & .070 & .076 \\
\hline Lassen Hall & .089 & .078 \\
\hline Mechoopda Hall & .102 & .099 \\
\hline Shasta Hall & .084 & .090 \\
\hline University Village & .081 & .087 \\
\hline Whitney Hall & .096 & .086 \\
\hline
\end{tabular}

Note. ${ }^{a} \underline{n}=807 .{ }^{b} \underline{n}=733$.

The mean number of drinks by residency of those CSU, Chico freshmen students drinking varied from year one and year two. In year one, the low number drinks was Konkow Hall (a thematic academic hall) with a mean of 5.2 to a high of 7.2 from Mechoopda Hall, or a range of 2.0. In year two, the low number of drinks was Konkow Hall with a mean of 4.4 to a high of 6.3 from University Village (see Table 22).

Table 22

Mean Number of Drinks of Those CSU, Chico Freshmen Students Who Had Been Drinking by Year and Residency

\begin{tabular}{|l|c|c|}
\hline & \multicolumn{2}{|c|}{ Year } \\
\hline Residence Hall & $\mathbf{2 0 0 1 - 2 0 0 2}^{\mathbf{a}}$ & $\mathbf{2 0 0 2 - 2 0 0 3}^{\mathbf{b}}$ \\
\hline Craig Hall & 6.9 & 6.1 \\
\hline Esken Hall & 5.6 & 6.0 \\
\hline Konkow Hall & 5.2 & 4.4 \\
\hline Lassen Hall & 5.9 & 5.5 \\
\hline Mechoopda Hall & 7.2 & 6.0 \\
\hline Shasta Hall & 5.9 & 5.9 \\
\hline University Village & 5.3 & 6.3 \\
\hline Whitney Hall & 6.9 & 5.7 \\
\hline
\end{tabular}

Note. ${ }^{a} \underline{n}=848 .{ }^{b} \underline{n}=815$.

\section{Previous Breath Test}

Given the nature of the sample it was possible for an individual to have been interviewed on numerous occasions. The percentage of CSU, Chico freshmen students reporting "yes" to having a previous BAC interview in year one was 29.5 percent and 29.2 percent in year two. Conversely, the percentage reporting "no" to having a previous BAC interview in year one was 70.5 percent and 70.8 percent in year two (see Table 23). 
Table 23

Percentage of CSU, Chico Freshmen Students Who Did or Did Not Have a Previous Blood Alcohol Concentration (BAC) Interview by Year

\begin{tabular}{|l|c|c|}
\hline & \multicolumn{2}{|c|}{ \% Year } \\
\hline Previous BAC & 2001-2002 $^{\mathbf{a}}$ & $\mathbf{2 0 0 2 - 2 0 0 3}^{\mathbf{b}}$ \\
\hline Yes & 29.5 & 29.2 \\
\hline No & 70.5 & 70.8 \\
\hline Totals $^{\mathrm{c}} \%$ & 100.0 & 100.0 \\
\hline
\end{tabular}

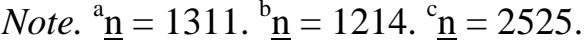

\section{Discussion}

\section{Overview of the Study}

This study assessed the data from the Freshmen Alcohol Abuse Program to explore the hypothesis that the introduction of the program was associated with a decrease in freshmen BAC levels for those students returning to their residence hall at night on CSU, Chico's campus from the academic years of 2001-2002 to 20022003. The Freshmen Alcohol Abuse Program was the combination of the Did You Know and Wanna Know campaigns. The Did You Know campaign was based upon the social norms theory, which asserts that students' misperceive the amount that other students' drink. Therefore, the Did You Know campaign attempted to align students' misperceptions of drinking behaviors with the campus norm. The Wanna Know campaign consisted of immediate feedback to participants by results from a breath test with a Breathalyzer ${ }^{\circledR}$ device to measure BAC levels. The Wanna Know interviews of CSU, Chico freshmen totaled 1,314 in year one and 1,215 in year two. In addition, the Did You Know campaign was the component that focused on distributing social norming messages to all CSU, Chico freshmen students. Interview results were analyzed using SPSS ${ }^{\circledR}$.

\section{Limitations of the Study}

In year one of the study, interviewers had interviewed some non-freshmen. This became clear when the number of freshmen that were older than 19 in the interviews were higher than the number who were enrolled in the total university. Thus, 105 interviews were discarded in year one on the assumption that they were not freshmen because they were age 20 or older. Also, a percentage may have misrepresented their class standing and age in order to be interviewed. However, this probably constituted a small percentage of the interviews used in this analysis. Therefore, those over 19 years old were excluded.

The results of this study do not represent CSU, Chico freshmen. The sample in this study was a nonprobability sample - a convenience sample. Each and every combination of freshmen students did not have an equal chance of being selected since those selected were those returning to various residence halls. Even freshmen students residing in the residence halls did not have an equal chance of being selected. Only students out late in the evening and early morning hours had a chance of being selected in the sample. Students who were interviewed may have over represented the population of CSU, Chico freshmen who stay out late and drink. Those students who do not drink may have been in the library studying or in their residence halls sleeping. The results of this study only apply to those students interviewed during the course of this study.

Another issue is that BAC levels do not represent the actual amount of alcohol that was consumed during the evaluation period. Students may have sobered up prior to the 
interview, therefore, it would show a low BAC level or none at all even though they had been drinking that day. The BAC level results should be compared with the number of drinks students reported drinking the day of the evaluation in order to get a broader picture of what occurred during those nights of investigation.

\section{Summary and Interpretation of Findings}

The mean BAC levels of CSU, Chico freshmen interviewed were .068 and .056 in year one and year two, respectively. This was a drop in BAC levels of .012, or a 21.4 percent decline. This decline was partially due to the 9.5 percentage point difference of .000 BAC levels from year one and year two, or a 37.3 percent increase. Therefore, I would accept my hypothesis that there was a decrease in CSU, Chico freshmen BAC levels for those who were heading home to their residence hall from year one and year two.

\section{External Variables}

A number of external variables other than the Freshmen Alcohol Abuse Program might account for the decrease in freshmen BAC levels. For example, the general economic condition could have been a factor in students overall spending behavior on alcohol. CSU, Chico freshmen parents may have been reluctant to give their teenager extra spending money due to the turbulent economic conditions. Tuition increases may also have had an impact on how much spending money that they would give to their teenager. Rather than parents giving their teenager an allowance it may have gone towards paying the tuition increase. Thus, the money was diverted into extra costs rather than on alcohol.

Furthermore, stricter policies for drinking on and off campus may have had an impact on the dependent variable BAC level. For example, residence halls hired more juniors and seniors that were more mature who could enforce the no alcohol rule in the residence halls. Also, the local Chico police increased enforcement by cracking down on minors in possession and those with open containers in public.
The increase of non-alcoholic activities on campus sponsored by the Associated Students may have diverted some freshmen students from going out and drinking. In year two, recreational sports offered more weekend activities and an increase of physical education classes were available Thursday, Friday, and Saturday.

Another external variable that may have contributed to a decrease in BAC levels is that there has been an emphasis on Greek houses being self-regulating organizations. That is, they have to abide by guidelines in order to be recognized by the university. In addition, those Greek houses supplying alcohol to minors will lose university recognition.

In year two, administrators encouraged professors to schedule exams, attendance taking, and papers due on Fridays. This may have deterred freshmen students from skipping their Friday classes and beginning their weekend of partying early. Thus, this could have dragged the mean BAC levels down in year two.

Finally, another possible variable is the increased emphasis on apartment owners and managers to crack down on underage drinking. CSU, Chico freshmen students who are under the legal age to drink could be evicted if caught drinking on the apartment premises. Students who throw big parties at their apartment may also be evicted, thus the fewer the parties the less likely freshmen students will be drinking.

It was interesting to see the sex differentials in relation to BAC levels. Females had lower BAC levels than males, which was consistent with the literature that females tend to drink less than males (Wechsler et al., 2003). Female BAC levels were .017 lower than the males from year one and year two. More females had .000 BAC levels than males in both years of the study. In fact, there was a 16.2 percentage point difference in BAC levels between males and females in year one. That gap narrowed in year two to a 7.2 percentage point difference. Furthermore, when eliminating students with .000 BAC levels from the analysis there were only minimal differences between males and 
females that had been drinking in year one and year two.

The mean number of drinks from year one and year two was 5.8, including those students who had not been drinking. This number represents the mean number of drinks that they had during the evaluation period. When eliminating those who did not drink during the evaluation period, the number of drinks increased in year one to 6.4 drinks and remained constant for year two with 5.8 drinks.

In addition, it was interesting to note that there were consistent differences between males and females who had been drinking in year one and year two of 2.0 drinks. Furthermore, when eliminating those who did not drink, the differences remained at 1.9 drinks in year one and year two, which is fairly consistent with the mean that included those who did not drink.

When analyzing the data by residence hall, the mean low number of hours and minutes spent drinking during the evaluation period was 1 hour and 31 minutes in Konkow Hall - a thematic residence hall consisting of honors students. However, in year two the mean hours and minutes for Konkow Hall increased to 3 hours and 17 minutes, or an increase of 1 hour and 46 minutes. Even though the mean number of hours and minutes increased for Konkow Hall their BAC levels and number of drinks were the lowest compared to other residence halls. Furthermore, the low was Shasta Hall in year two with 2 hours and 38 minutes and the high was Craig Hall with 4 hours and 39 minutes. In year two, only Esken Hall, Mechoopda Hall, Whitney Hall had a decrease in the mean number of hours and minutes spent drinking. The most notable decrease was 44 minutes in Mechoopda Hall. Overall, it is difficult to discern general patterns when analyzing the data by residence hall.

There were differences between type of drink and sex of the interviewees in year one and year two. Most notably was that males interviewed drank more beer than females. For example, in year one and year two there was a 22.4 and 18.1 percentage point difference between male and female beer consuming patterns. This drinking pattern could be the result of female awareness that beer contains more calories than other types of drinks (S. M. Quinn, personal communication, April 12, 2004).

From year one and year two drinking patterns for combination drinks remained relatively constant between males and females. However, females drank more liquor than the males. In year one and year two there was a 22.5 and 17.6 percentage point difference between males and females in liquor consumption - almost the exact reversal of beer drinking patterns. Again, females may have opted for the type of drink with the lowest calories. Wine was rarely the choice of drink for either males or females in year one and year two.

The mean dollars spent for those who had BAC levels above .000 showed interesting patterns. CSU, Chico freshmen females interviewed spent less than males in year one and year two. This makes sense since many parties around Chico do not require females to pay for their alcohol. Even the mean amount spent by the males seems too low considering the price of beverages. Upon further investigation, students generally pay a fee at a party of roughly $\$ 5.00$ for a cup, which allows them to obtain drinks from the keg for the rest of the evening. The high value for both males and females was $\$ 150.00$ for one evaluation period, which would be consistent for a price of two kegs. These students may have bought them for an open party. In year two, the high values increased for males and females to $\$ 240.00$ and $\$ 180.00$, respectively. The increase could be associated with more students buying kegs in year two, and more of them, and possibly they added the mandatory deposit as money spent on alcohol, even though they received the deposit back if they fulfilled their contract. Females generally do not have to spend as much money as males on alcohol at an open party. Also, alcohol may have been given away at no cost to either males or females.

Regardless how much students drank, the number reported "yes" to drinking the day of the evaluation period. In year one, 84.6 percent of the males and 73.4 percent of the females 
reported "yes" to drinking the day of the evaluation period, or a difference of 11.2 percentage points. In year two, those reporting "yes" to drinking the day of the evaluation decreased, 77.1 percent of the males and 65.2 percent of the females reported drinking the day of the evaluation period, a difference of 11.9 percentage points. Thus, the percent of males drinking during the evaluation declined between year one and year two by 9.7 percent, and females declined by 12.6 percent.

CSU, Chico freshmen students in the study obtained their drinks predominantly from a friend's residence in year one and year two. Generally freshmen students are not of age to legally drink, therefore, they must rely on others' to obtain their alcohol. Bars and stores have improved their methods of spotting fake drivers licenses and other forms of identification. In year one, 14.4 percent obtained their drinks from the store themselves, whereas, in year two only 5.6 percent obtained their drinks in this manner. Students' obtaining their alcohol in the residence halls went up in year two from 9.1 percent to 13.7 percent. Stricter rules and non-passive resident advisors enforcing the rules may reduce such increases in the future.

Analyzing the data by residence hall and BAC levels of those CSU, Chico freshmen students interviewed showed interesting results. The low and high BAC levels for those students who had been drinking remained Konkow and Mechoopda Hall, respectively. Again, upon speculation it would appear that since Konkow Hall was an academic thematic residence hall, the academic emphasis factor may have had an influence on the BAC levels of those freshmen students.

Craig Hall, Esken Hall, Lassen Hall, Mechoopda Hall, and Whitney Hall had a decrease in their BAC levels between years one and year two, although they were minimal. For example, the low decrease was Esken Hall with .001 BAC and the high decrease was Lassen Hall with .011 BAC. Konkow Hall, Shasta Hall, and University Village each had a .006 BAC increase from year one to year two. Overall, there were slight fluctuations from year one and year two, however, those halls with the highest and lowest BAC levels remained fairly constant.

There were variations from year one and year two when analyzing the data by residence hall and mean number of drinks. There was a decrease in the mean number of drinks in Craig Hall, Konkow Hall, Lassen Hall, Mechoopda Hall, and Whitney Hall. The most notable decreases were from Mechoopda and Whitney Hall with a decrease of 1.2 drinks. Shasta Hall stayed at a mean number of drinks of 5.9 in both years. The mean number of drinks in Esken Hall and University Village increased .4 and 1.0 drinks from year one and year two. Overall, it was difficult to discern general patterns of residence hall and BAC levels.

It was interesting that 57.6 and 52.4 percent of those CSU, Chico freshmen students interviewed who had been drinking had BAC levels at or above .080 , the legal limit for intoxication in the State of California. Although, drinking under age 21 is illegal under any circumstances, these students surpassed the legal drinking limit for driving. Therefore, if they were age 21 and above and had been drinking, they could have been given citations for driving under the influence (DUI). In addition, this does not represent students' peak BAC levels since many of them may have stopped drinking prior to receiving a breath test.

\section{Recommendations for Further Research}

Further research may include assessing if students align their drinking behavior to their immediate social group or if they align it with their perceptions of their university. Further research may disclose that residents of academic thematic halls were serious students prior to entering college. Therefore, it may not have made much of a difference if they were living in a standard hall. However, this entire area could be a focus of further research. Also, further research for on campus policies and programs would be of interest.

This study suggests that using breath testing can have positive results. In addition, there needs to be a study conducted to see if this experience 
lasts throughout the students' undergraduate career compared to students who did not go through this program. Furthermore, replication of this study should be conducted at other campuses.
Ideally, a longitudinal panel analysis could be conducted to chart drinking patterns throughout a students' academic career. This study would be able to track a student from their freshmen, sophomore, junior and senior year.

\section{References}

Agostinelli, G., Brown, J. M., \& Miller, W. R. (1995). Effects of normative feedback on consumption among heavy drinking college students. Journal of Drug Education, 25(1), 31-40.

Agostinelli, G., \& Miller, W. R. (1994). Drinking and thinking: How does personal drinking affect judgments of prevalence and risk? Journal of Studies on Alcohol, 55, 327-337.

Alco Sensor IV-Intoximeters. (2004). Retrieved February 15, 2004, from http://www.intox.com/product_pdfs/www Alco-SensorIV.pdf

America's best colleges 2004: Universities-master's (West): Top publics. (2004). U.S. News and World Report. Retrieved February 18, 2004, from http://www.usnews.com/usnews/edu/college/rankings/brief/univmas/umwest/univmas_w_pub_bri ef.php

America's best colleges 2004: Western universities-master's: Top schools. (2004). U.S. News and World Report. Retrieved February 18, 2004, from http://www.usnews.com/usnews/edu/college/rankings/brief/univmas/umwest/tier1/t1univmas_w_ brief.php

Baer, J. S. (1994). Effects of college residence on perceived norms for alcohol consumption: An examination of the first year of college. Psychology of Addictive Behaviors, 8, 43-50.

Baer, J. S., \& Carney, M. M. (1993). Biases in the perceptions of the consequences of alcohol use among college students. Journal of Studies on Alcohol, 54, 54-60.

Baer, J. S., Stacy, A., \& Larimer, M. (1991). Biases in the perception of drinking norms among college students. Journal of Studies on Alcohol, 52, 580-586.

Barnett, L. A., Far, J. M., Maus, A. L., \& Miller, J. A. (1996). Changing perceptions of peer norms as a drinking reduction program for college students. Journal of Alcohol and Drug Education, 41(2), 39-61.

Beck, K. H., \& Treiman, K. A. (1996). The relationship of social context of drinking, perceived social norms, and parental influence to various drinking patterns of adolescents. Addictive Behaviors, 21, 633-644.

Berkowitz, A. D. (1997). From reactive to proactive prevention: Promoting an ecology of health on campus. In P. C. Rivers, \& E. Shore (Eds.), A handbook on substance abuse for college and university personnel (Chapter 6). Westport, CT: Greenwood Press.

Berkowitz, A. D. (2003). The social norms approach: Theory, research, and annotated bibliography. Retrieved September 3, 2003, from U.S. Department of Education's Higher Education Center for Alcohol and other Drug Prevention Web site: http://www.edc.org/hec/socialnorms/theory.html

Berkowitz, A. D., \& Perkins, H. W. (1986). Resident advisors as role models: A comparison of drinking patterns of resident advisors and their peers. Journal of College Student Personnel, 27(2), 146153.

Bizjak, T. (1990, May 13). Chico searches its heart after riots. The Sacramento Bee, pp. A1, A20.

Bourgeois, M. J., \& Bowen, A. (2001). Self-organization of alcohol-related attitudes and beliefs in a campus housing complex: An initial investigation. Health Psychology, 20(6), 1-4.

Carnegie Foundation for the Advancement of Teaching. (1990). Campus life: In search of community. Princeton, NJ: Author.

Carter, C. A., \& Kahnweiler, W. M. (2000). The efficacy of the social norms approach to substance abuse prevention applied to fraternity men. Journal of American College Health, 49, 66-71. 
Choat, M. (2002, October 2). "Playboy” ranks top party schools. The Orion On-line. Retrieved February 18, 2004, from http://www.orion-online.net/vnews/display.v/ ART /2002/10/02/3d9a168e6e329?in archive $=1$

Clapp, J. D., \& McDonnell, A. L. (2000). The relationship of perceptions of alcohol promotion and peer drinking norms to alcohol problems reported by college students. Journal of College Student Development, 41(1), 20-26.

Clapp, J. D., Russell, C., \& DeJong, W. (2001, July). Done 4 did zip: Evaluating a failed social norms marketing campaign. Paper presented at the fourth national conference on the social norms model, Anaheim, CA.

DeJong, W. (2000). Report to the field: The case of the missing misperception. Retrieved July 20, 2004, from U.S. Department of Education, Higher Education Center for Alcohol and Other Drug Prevention Web site: http://www.edc.org/hec/press-releases/001013.html

DeJong, W., \& Langford, L. M. (2002). A typology for campus-based alcohol prevention: Moving toward environmental management strategies. Journal of Studies on Alcohol, 14, 140-147.

Duvall, W. (1987, January). Top 40 party colleges. Playboy, 173-177.

Fabiano, P. (2003). Applying the social norms model to universal and indicated alcohol interventions at Western Washington University. In H. W. Perkins (Ed.), The social norms approach to preventing school and college age substance abuse: A handbook for educators, counselors, clinicians (Chapter 5). San Francisco: Jossey-Bass.

Far, J., \& Miller, J. (2003). The small group norms challenging model: Social norms interventions with targeted high risk groups. In H. W. Perkins (Ed.), The social norms approach to preventing school and college age substance abuse: A handbook for educators, counselors, clinicians (Chapter 7). San Francisco: Jossey-Bass.

Flinn, J. (1989, May 7). Chico campus runs wild over pioneer festival. San Francisco Examiner, pp. B1, B6.

Gimblin, S. (2004). Party school image flunks out. The Orion On-line. Retrieved February 12, 2004, from http://www.orion-online.net/vnews/display.v/ART/2004/01/08/3ffb542543a28?in archive=1

Glindemann, K. E., Geller, E. S., \& Fortney, J. N. (1999). Self-esteem and alcohol consumption: A study of college drinking behavior in a naturalistic setting. Journal of Alcohol and Drug Education, 45(1), 60-71.

Glindemann, K. E., Geller, E. S., \& Ludwig, T. D. (2001). Behavioral intentions and blood alcohol concentration: A relationship for prevention intervention. Journal of Alcohol and Drug Education, 41(2), 120-134.

Glider, P., Midyett, S., Mills-Novoa, B., Johannessen, K., \& Collins, C. (2001). Challenging the collegiate rite of passage: A campus-wide social marketing media campaign to reduce binge drinking. Journal of Drug Education, 31, 207-220.

Gomberg, L., Schneider, S. K., \& DeJong, W. (2001). Evaluation of a social norms marketing campaign to reduce high-risk drinking at the University of Mississippi. American Journal of Drug and Alcohol Abuse, 27, 375-389.

Haines, M. P. (1996). A social norms approach to preventing binge drinking at colleges and universities, Newton, MA: The Higher Education Center for Alcohol and Other Drug Prevention.

Haines, M. P., \& Barker, G. P. (2003). The NIU experiment: A case study of the social norms approach. In H. W. Perkins (Ed.), The social norms approach to preventing school and college age substance abuse: A handbook for educators, counselors, clinicians (Chapter 2). San Francisco: Jossey-Bass.

Haines, M. P., Barker, G. P., \& Rice, R. (2003). Using social norms to reduce alcohol and tobacco use in two Midwestern high schools. In H. W. Perkins (Ed.), The social norms approach to preventing school and college age substance abuse: A handbook for educators, counselors, clinicians (Chapter 14). San Francisco: Jossey-Bass.

Haines, M. P., \& Spear, S. F. (1996). Changing the perception of the norm: A strategy to decrease binge drinking among college students. Journal of American College Health, 45, 134-140. 
Hancock, L., \& Henry, N. (2003). Perceptions, norms and tobacco use in college residence hall freshmen: Evaluation of a social norms marketing intervention. In H. W. Perkins (Ed.), The social norms approach to preventing school and college age substance abuse: A handbook for educators, counselors, clinicians (Chapter 8). San Francisco: Jossey-Bass.

Hansen, W. B., \& Graham, J. W. (1991). Preventing alcohol, marijuana, and cigarette use among adolescents: Peer pressure resistance training versus establishing conservative norms. Preventive Medicine, 20, 414-430.

Institutional Research. (2004). Common data set: California State University, Chico. Retrieved April 22, 2004, from http://safari.csuchico.edu/CDS/CDSIndex.htm

Jeffrey, L. R., Negro, P., Demond, M., \& Frisone, J. D. (2003). The Rowan University social norms project. In H. W. Perkins (Ed.), The social norms approach to preventing school and college age substance abuse: A handbook for educators, counselors, clinicians (Chapter 6). San Francisco: Jossey-Bass.

Johannessen, K. J., Collins, C., Mills-Novoa, B. M., \& Glider, P. (1999). A practical guide to alcohol abuse prevention: A campus case study in implementing social norms and environmental management approaches. Retrieved July 1, 2004, from The Higher Education Center for Alcohol and Other Drug Prevention Web site: http://www.edc.org/hec/socialnorms/references.html

Johannessen, K., \& Glider, P. (2003). The University of Arizona’s campus health social norms media campaign. In H. W. Perkins (Ed.), The social norms approach to preventing school and college age substance abuse: A handbook for educators, counselors, clinicians (Chapter 4). San Francisco: Jossey-Bass.

Larimer, M. E., Irvine, D. L., Kilmer, J. R., \& Marlatt, G. A. (1997). College drinking and the Greek system: Examining the role of perceived norms for high-risk behavior. Journal of College Student Development, 38(6), 587-598.

Linkenbach, J., \& Perkins, H. W. (2003). Most of us are tobacco free: An eight month social norms campaign reducing youth initiation of smoking in Montana. In H. W. Perkins (Ed.), The social norms approach to preventing school and college age substance abuse: A handbook for educators, counselors, clinicians (Chapter 13). San Francisco: Jossey-Bass.

Page, R. M., Scanlan, A., \& Gilbert, L. (1999). Relationship of the estimation of binge-drinking among college students and personal participation in binge drinking: Implications for health education and promotion. Health Education, 30, 98-103.

Peeler, C. M., Far, J., Miller, J., \& Brigham, T. (2000). An analysis of the effects of a program to reduce heavy drinking among college students. Journal of Alcohol and Drug Education, 45, 39-54.

Perkins, H. W. (1985). Religious traditions, parents, and peers as determinants of alcohol and drug use among college students. Review of Religious Research, 27(1), 15-31.

Perkins, H. W. (1987). Parental religion and alcohol use problems as intergenerational predictors of problem drinking among college youth. Journal for the Scientific Study of Religion, 26, 340-357.

Perkins, H. W. (1997). College student misperceptions of alcohol and other drug use norms among peers. In Designing alcohol and other drug prevention programs in higher education: Bringing theory into practice (pp. 177-206). Newton, MA: The Higher Education Center for Alcohol and Other Drug Prevention.

Perkins, H. W. (2003a). The emergence and evolution of the social norms approach to substance abuse prevention. In H. W. Perkins (Ed.), The social norms approach to preventing school and college age substance abuse: A handbook for educators, counselors, clinicians (Chapter 1). San Francisco: Jossey-Bass.

Perkins, H. W. (2003b). The promise and challenge of future work on the social norms model. In H. W. Perkins (Ed.), The social norms approach to preventing school and college age substance abuse: A handbook for educators, counselors, clinicians (Chapter 17). San Francisco: Jossey-Bass.

Perkins, H. W., \& Berkowitz, A. D. (1986). Perceiving the community norms of alcohol use among students: Some research implications for campus alcohol education programming. International Journal of the Addictions, 21, 961-976. 
Perkins, H. W., \& Craig, D. A. (2002). A multi-faceted social norms approach to reduce high-risk drinking: Lessons from Hobart and William Smith Colleges. Newton, MA: The Higher Education Center for Alcohol and Other Drug Prevention.

Perkins, H. W., \& Craig, D. A. (2003a). The Hobart and William Smith Colleges experiment: A synergistic social norms approach using print, electronic media and curriculum infusion to reduce collegiate problem drinking. In H. W. Perkins (Ed.), The social norms approach to preventing school and college age substance abuse: A handbook for educators, counselors, clinicians (Chapter 17). San Francisco: Jossey-Bass.

Perkins, H. W., \& Craig, D. A. (2003b). The imaginary lives of peers: Patterns of substance use and misperceptions of norms among secondary school students. In H. W. Perkins (Ed.), The social norms approach to preventing school and college age substance abuse: A handbook for educators, counselors, clinicians (Chapter 12). San Francisco: Jossey-Bass.

Perkins, H. W., Meilman, P. W., Leichliter, J. S., Cashin, M. A., \& Presley, C. A. (1999). Misperceptions of the norms for the frequency of alcohol and other drug use on college campuses. Journal of American College Health, 47, 253-258.

Perkins, H. W., \& Wechsler, H. (1996). Variation in perceived college drinking norms and its impact on alcohol abuse: A nationwide study. Journal of Drug Issues, 26, 961-974.

Pollard, J. W., Freeman, J. E., Ziegler, D. A., Hersman, M. N., \& Goss, C. W. (2000). Predictions of normative drug use by college students: False consensus, false uniqueness, or just plain accuracy? Journal of College Student Psychotherapy, 14(3), 5-12.

Prato, A. (2002, November). Playboy’s top 25 party school’s. Playboy, 89-91, 156-157.

Prentice, D. A., \& Miller, D. T. (1993). Pluralistic ignorance and alcohol use on campus: Some consequences of misperceiving the social norm. Journal of Personality and Social Psychology, 64, 243-256.

Rosenthal, R., \& Jacobson, L. (1968). Pygmalion in the classroom: Teacher expectation and pupils' intellectual development. New York: Holt, Rinehart \& Winston.

Ross, L., Greene, D., \& House, P. (1977). The "false consensus effect": An egocentric bias in social perception and attribution processes. Journal of Experimental Social Psychology, 13, 279-301.

Schafer, W. E. (2001). Prevent high-risk drinking and violent behavior among college students. Unpublished manuscript, California State University, Chico.

Schafer, W. E., \& Duerr, M. (2003). Social norming and breath sampling: Preventing high-risk drinking among first-year university students. Unpublished manuscript, California State University, Chico.

Schroeder, C. M., \& Prentice, D. A. (1998). Exposing pluralistic ignorance to reduce alcohol use among college students. Journal of Applied Social Psychology, 28, 2150-2180.

Sher, K., Bartholow, B. D., \& Nanda, S. (2001). Short- and long-term effects of fraternity and sorority membership on heavy drinking: A social norms perspective. Psychology of Addictive Behaviors, $15,42-51$.

Steffian, G. (1999). Correction of normative misperceptions: An alcohol abuse prevention program. Journal of Drug Education, 29(2), 115-138.

Suls, J., \& Wan, C. K. (1987). In search of the false-uniqueness phenomenon: Fear and estimates of social consensus. The Journal of Personality and Social Psychology, 52, 211-217.

Task Force of the National Advisory Council on Alcohol Abuse and Alcoholism. (2002). A call to action: Changing the culture of drinking at U.S. colleges. Retrieved April 21, 2004, from http://www.collegedrinkingprevention.gov/Reports/\#task

Thombs, D. L. (1999). Alcohol and motor vehicle use: Profiles of drivers and passengers. American Journal of Health and Behavior, 23, 13-24.

Thombs, D. L. (2000). A test of the perceived norms model to explain drinking patterns among university student athletes. Journal of American College Health, 49, 75-83.

Thombs, D. L., Wolcott, B. J., \& Farkash, L. G. E. (1997). Social context, perceived norms and drinking behavior in young people. Journal of Substance Abuse, 9, 257-267.

Triola, M. F. (1995). Elementary statistics (6th ed.). New York: Addison-Wesley. 
Vau Dell, T. (2001, February 6). Fraternity members get 30 days in jail. Enterprise Record, pp. 1A, 7A. Vau Dell, T. (2002, October 25). Heidemans settle suit with national fraternity. Enterprise Record, pp. $1 \mathrm{~A}, 12 \mathrm{~A}$.

Wechsler, H., \& Kuo, M. (2000). College students define binge drinking and estimate its prevalence: Results of a national survey. Journal of American College Health, 49, 57-64.

Wechsler, H., et al. (2003). Perception and reality: A national evaluation of social norms marketing interventions to reduce college students' heavy alcohol use. Journal of Studies on Alcohol, 64, 484-494.

Werch, C. C. E., Pappas, D. M., Carlson, J. M., DiClemente, C. C., Chally, P. S., \& Sinder, J. A. (2000). Results of a social norm intervention to prevent binge drinking among first-year residential college students. Journal of American College Health, 49, 85-92.

Wolfson, S. (2000). Student's estimates of the prevalence of drug use: Evidence for a false consensus effect. Psychology of Addictive Behaviors, 14, 295-298.

\section{Acknowledgements}

I want to thank the thesis chair, Dr. Clark Davis, for being the most influential person in my life. Without his encouragement I would not have pursued graduate studies.

Furthermore, Dr. Schafer was helpful during the writing process of this thesis by providing insightful feedback on many drafts. Above all he was the designer of the Freshmen Alcohol Program and successfully obtained funds from the Department of Education to undertake this study.

In addition, Dr. Mark Tomita and Roland Lamarine were invaluable committee members on this thesis.

Author Information

J. Joshua Brown, M.A.

Department of Social Science and Special Programs

California State University, Chico

400 W. First St.

Chico, CA 95929-0002

E-mail: jjoshuabrown@yahoo.com 


\section{Appendix A}

Test Subject Check-List

Date:

Time:

Interviewer:

Breath Test \#:

Is subject a freshman?

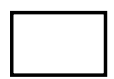

Is subject heading home for the night?

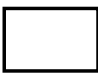

Did you explain the protocol briefly?

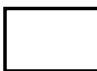

Did you take the subject away from the group?

Did you/nurse show the BAC results only to the subject?

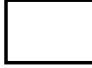

Did you give the subject a “Did You Know?” message? 


\section{Appendix A continued}

Breathalyzer Event Interview Questions

Test Subject: Male Female

1. What is your age?

2. Are you a freshman at CSU, Chico? YES NO

3. Do you live in the residence halls? If so, which one?YES NO

\section{Whitney Mechoopda Esken Lassen Shasta University Village Craig Hall}

4. Have you taken one of our breath tests before? If so, how many times?

YES NO

5. At what age did you have your first drink?

6. Before attending CSU, Chico, did you drink MORE, LESS, THE SAME as you do now?

7. Have you had any alcoholic beverages today? (If no, go directly to question 14)

YES NO

8. A drink is a shot of liquor, 12-oz. beer or 5-oz. glass of wine. How many drinks did you have? What did you drink?

NUMBER OF DRINKS:

BEER

WINE

LIQUOR

COMBINATION

9. What time did you begin drinking today?

10. What time did you stop drinking?

(Interviewer: Amount of time drinking:

11. What is your approximate weight?

12. How much money did you spend on alcohol for yourself today?

13. Where did you obtain your drinks today? (circle as many as apply)

At an open party (not sorority or fraternity) In a residence hall

At a fraternity or sorority

Outside a residence hall

At a friend's residence

In my own home or room 
At a store (Who bought it? •Self • Someone else At my parent's home

At a bar (Who bought it? •Self • Someone else Other:

14. What do you think your blood alcohol concentration is right now?

Breathalyzer test administered at this point.

Breathalyzer test \#:

BAC level :

While subject is being tested, ask a friend what his/her perception of subject's BAC level is.

15. How many drinks do you think most CSU, Chico students' consume at off-campus parties?

FACTS: Our most recent random-sample survey of over 800 CSU, Chico students in spring 2001 showed that most students OVER-ESTIMATE how much other students drink. In fact, MOST CSU, CHICO STUDENTS CONSUME BETWEEN 0-4 DRINKS AT OFF-CAMPUS PARTIES.

THANK STUDENTS FOR PARTICIPATING

GIVE THE PARTICIPANTS A BROCHURE AND BAC CHART

DELIVER A SOCIAL NORMING MESSAGE

LET THEM CHOOSE A T-SHIRT OR WATER BOTTLE

GIVE .000 STUDENTS A GIFT CERTIFICATE 